\title{
Clandestine Recruitment Networks in the Bight of Biafra: Fernando Pó's Answer to the Labour Question, I926-I945*
}

\author{
ENRIQUE MARTINO \\ Institute of Asian and African Studies, Humboldt University Berlin
}

E-mail: enrique.martino@gmail.com

SUMmARY: The "Labour Question", a well-known obsession pervading the archives of Africa, was posed by colonial rulers as a calculated question of scarcity and coercion. On the Spanish plantation island of Fernando Pó the shortage and coercive recruitment of labour was particularly intense. This article examines two distinct clandestine labour recruitment operations that took hold of Rio Muni and eastern Nigeria, on the east and the north of the Bight of Biafra. The trails of the recruitment networks were successfully constructed by the specifically aligned "mediators" of kinship, ethnicity, money, law, commodities, and administration. The conceptual focus on flat "mediators" follows Bruno Latour's sociology of associations and has been set against the concept of an "intermediary" that serves to join and uphold the structure/agency and global/local binaries.

A disappearing Spanish Empire had wedged itself into the Bight of Biafra. Charted by Portuguese navigators and bound by the slave trade, this corner of the Atlantic was for the first two-thirds of the twentieth century embroiled in the colonial struggle for "manpower". The so-called "Labour Question", a well-known obsession pervading the archives of Africa, was

\footnotetext{
* This research has benefited from the financial support of ERC Starting Grant no. 240898 under Framework Programme 7 of the European Commission, which funds the Research Group "Forced Labour Africa: An Afro-European Heritage in Sub-Saharan Africa (1930-1975)". I am most grateful for the generous suggestions and corrections of Alexander Keese, Andreas Eckert, Sabine Scheuring, Ineke Phaf-Rheinberger, and Joel Glasman, and of course to the editors of the present Special Issue. Most of the sources referenced are from one Spanish archive, for which the following abbreviations have been used: AGA = Archivo General de la Administración, Alcalá de Henares, Spain, IDD is, Fondo África; C = Caja; $\mathrm{E}=$ Expediente; $\mathrm{DGMC}=$ Dirección General de Marruecos y Colonias (Colonial Office, Madrid); $G G=$ Gobernador General de Guinea (Governor, Santa Isabel); GG Bata= Subgobernador General de la Guinea Continental (Lieutenant Governor, Bata); Curaduria = Curaduría Colonial (Labour Office, Santa Isabel); Cámara = Cámara Agrícola de Fernando Póo (Agricultural Chambers of Commerce, Santa Isabel).
} 
posed by colonial rulers as a calculated question of scarcity and coercion. In Spanish Guinea the shortage and compulsory recruitment of labour was unusually pronounced. On the island of Fernando Pó la cuestión bracera had revived the economic logic of the Caribbean plantation. With the indigenous Bubi population decimated by disease and forced labour, the island's economy came to depend on imported braceros - the Spanish term for agricultural contract workers derived from the word for arms. Towards the end of the Atlantic slave trade and the long imperial nineteenth century, these braceros included Cuban political prisoners and freed slaves, "coolie" workers from China, itinerant Kru sailors from the Windward Coast contracted into bondage, and, most infamously, tens of thousands of indentured labourers from Liberia.

Recruitment and even labour migration to the sole remnant of equatorial Spanish colonialism, by then reduced to the size of Belgium, was explicitly prohibited by all other European empires. The labour supply from the Republic of Liberia was cut off in 1930 after a well-publicized intervention by the International Labour Organization (ILO), whereupon the obscure colony became popularly known, from Monrovia to Geneva and from London to Lagos, as "the island of no return". Surrounded by boycotts and their own notoriety, the planters on Fernando Pó, who were producing about 2 per cent of the world's cacao, sought out underground labour suppliers in an attempt to scramble themselves out of the paralysing labour shortage on the island. As the archival material unearthed here will show, planters relied on two distinct and successive clandestine labour recruitment operations in Rio Muni and Nigeria to the east and north of the Bight of Biafra. The scale of clandestine recruitment was, in its region, period, and proportionate dimension, unparalleled. ${ }^{\mathrm{I}}$

In 1926 Fernando Pó turned to its continental exclave Rio Muni, and transformed the border zones with Gabon and Cameroon into a labour reserve for Spanish recruiters. What Catherine Coquery-Vidrovitch called "the plague of recruiters" unleashed decades earlier across the hinterlands of resource-extraction works in central and southern Africa reached Rio Muni with a time-lag, and a vengeance. ${ }^{2}$ As a Spanish territory, it had

I. The techniques used by the island's recruiters, which at the least can be described as audacious and cunning, have their parallels throughout colonial constellations of capital and labour. See, especially, Alan Jeeves, Migrant Labour in South Africa's Mining Economy: The Struggle for the Gold Mines' Labour Supply, I890-1920 (Johannesburg, 1985); the Peru case study in Tom Brass, Towards a Comparative Political Economy of Unfree Labour (London, 1999); and the case study of a plantation island in New Guinea in Marcel van der Linden, Workers of the World: Essays Toward a Global Labor History (Leiden, 2008), pp. 339-358.

2. Catherine Coquery-Vidrovitch, "The Colonial Economy of the Former French, Belgian and Portuguese Zones, I9I4-35”, in Adu Boahen (ed.), General History of Africa, VII, Africa Under Colonial Domination I880-1935 (Paris [etc.], 1985), pp. 351-382, 363; André Gide, Voyage an Congo (Paris, 1927), p. 72. 
been a haven for Fang escaping German and French forced-labour regimes, but in just a few years the Spanish were close to subjecting the entire male population of working age to forced labour on the mainland and to contract labour on the island. The first part of this essay covers the period of the Primo de Rivera dictatorship and the Second Republic, which lasted from I93 I to I936, and will document the free rein given to private recruiters and their lawless methods, to which the Spanish authorities turned a (permissive) blind eye. The labour reforms initiated at the end of the short-lived republic led to the dispersal of the Spanish recruiters of Rio Muni and prompted the transition to complete dependence on Nigerian recruiters.

The second part of the essay traces the recruitment constellation that took hold of Nigeria's eastern provinces. From Calabar and Victoria to Santa Isabel, the trickle of small traders and recruiters, using counterfeit papers on ferry boats, turned into a wholesale smuggling network on canoes which brought over tens of thousands of Ibibio and Igbo workers. The outbreak of the Spanish Civil War left the then fascist island of Fernando Pó financially and diplomatically isolated until the end of World War II, which entrenched the illegal canoe trade along the sharpest edge of the Bight of Biafra. Around 1940, in the aftermath of the Great Depression in Nigeria, and with Calabar's merchants seeking profitable new ventures, the proportion of illegally recruited workers stood, astoundingly, at 10 per cent of Nigeria's wage-employed population. ${ }^{3}$ Even in the post-World-War-II decades, the amount of migrant labour, disenfranchized and doubly discriminated against in Spanish Guinea, was large enough to contradict Frederick Cooper's or Carolyn Brown's positing of the late colonial period as a time when wage labourers turned to nationalist protest and claimed entitlements through orthodox classbased means. ${ }^{4}$

While only the "long decade" of the I930s falls within the scope of this essay, this important period signals the beginning of labour reforms in most African colonies, as labour departments and protective legislation were widely introduced after a spate of ILO treaties on forced labour, and

3. Heinrich Wieschhoff, Colonial Policies in Africa (Philadelphia, PA, 1944), p. 38; Granville St John Orde-Browne, Labour Conditions in West Africa (London, I94I), p. 79. The figure in 1938 for those in waged employment was 182,600 , of which 50,000 each were employed in mines and government, in a Nigerian population of 2 I million. For mines, see William Freund, "Labour Migration to the Northern Nigerian Tin Mines, 1903-1945", Journal of African History, 22 (198I), pp. 73-84.

4. Frederick Cooper, Decolonization and African Society: The Labor Question in French and British Africa (Cambridge, I996), see esp. parts 2 and 4, as well as his ongoing research; Carolyn A. Brown, "We Were All Slaves": African Miners, Culture, and Resistance at the Enugu Government Colliery (Oxford, 2003). For an overview see Andreas Eckert, "Geschichte der Arbeit und Arbeitergeschichte in Afrika”, Archiv für Sozialgeschichte, 39 (1999), pp. 502-530. 
the recruitment of and contracts for "indigenous workers". In a progressivist narrative the interwar years would mark the transition from unfree to free labour in African history.

In terms of labour recruitment, empires in Africa sought to shorten the distance from the Asian-based indentured labour market and to hasten the end of their "initial" - drawn-out and recurring - stage of administratively directed forced labour. The replacement would be a framework where employers could hire voluntary workers under the guidance of stateregulated international conventions and licensed agencies. The two recruitment constellations examined here fall into neither of those temporal "stages" because they cannot be categorized by the binary pairs of free/unfree and legal/illegal correlated by the modern state. That constant and shady borderland was home to a para-state, quasi-open market of trafficking entrepreneurialism. By operating on the edges of the Bight of Biafra the illegal recruiters circumvented the police state and disrupted the institutionalization of regulated labour markets. They pocketed an enormous share of the colonial economy of the island, which they also underpinned. The recruiters were paid, but through a series of very elaborate transactions they had to pay the costs of displacement, and every cent and metre had to be accounted for.

The empirical tracing of the recruitment networks leads to a prolonged focus on the institution of bridewealth in the Fang societies of Rio Muni and the trading and merchant structures of the Igbo and Efik of south-eastern Nigeria. The often underestimated role of kinship and ethnicity in structuring labour migration and recruitment has been highlighted by Ravi Ahuja. His unique research on South Asian maritime labourers has wonderfully reconstructed how colonial "networks of subordination" were accompanied by the "networks of the subordinated", that were neither "surviving elements of pre-capitalist societies nor solely infrastructures of resistance". ${ }^{6}$ However, as the empirical tracing of the recruitment networks includes the even more often underestimated role of non-human actors, such as currencies, travel documents, labour laws, and contraband goods, the theoretical inclination in this piece relies on Bruno Latour's sociology of associations rather than on the conceptual reservoirs of social history.

Latour's controversial method prohibits scientific "purification" that reduces socio-technical processes to singular causes, such as the nature of

5. Only Portugal refused to even sign the ILO conventions of 1930, I936, and 1939, and while only Britain ratified them expeditiously, they carried a rhetorical and international legal weight. See part I of Cooper, Decolonization and African Society.

6. Ravi Ahuja, "Networks of Subordination-Networks of the Subordinated: The Ordered Spaces of South Asian Maritime Labour in an Age of Imperialism (c.1890-1947)", in Ashwini Tambe and Harald Fischer-Tiné (eds), The Limits of British Colonial Control in South Asia: Spaces of Disorder in the Indian Ocean Region (London, 2009), pp. 13-48, 33. 
the market or class, power, and imperialism. With Latour, phantom master concepts are deflated and demystified to the extent that they can no longer be causally posited "below", nor be used as shortcuts to explain deductively almost everything else as mere effects, expressions, and reflections thereof. In Latour's laboratory the privileged lens that splits the abstract from the concrete to attain largely hollow structures disintegrates and, as if with the wave of a wand, hitherto passive actors and restricted contexts come to life in "a world made of concatenations of mediators where each point can be said to fully act". The magic comes from a flat ontology and a radicalized empiricism that "tries to replace as many causes as possible by a series of actors - such is the technical meaning of the word "network"'?

A "network" is not merely the loose and uninspiring middle ground between structure and agency or the local and the global. In Latour's methodological terms, after "localizing the global" and, with equal weight, "dislocalizing" or "redispatching the local", comes the work of "connecting sites". Even though Latour rejects the term "actor-network theory", preferring instead a magmatic totality of a "plasma of actants", he endorses its famous acronym. ANT encapsulates his methodological maxim: to follow the actors, and to do it as painstakingly as ants might, had they been set to work on the shelves of an archive. An ANT approach has been enabled by the Africa collection in the Spanish archive as it is actually "un-archived": the bulk of the documentation was never filtered or indexed. In this text, the aim has not been to mirror the already purified form of the well-structured colonial reports occasionally encountered, but, with the sources of all scales side by side, to reflect in method, map-making, and writing, the data cascades contained in a series of archival sheets, files, and boxes.

\section{RIO MUNI OVERRUN BY RECRUITERS, 1926-1935}

In the main square in Santa Isabel there once stood a statue of Governor Ángel Barrera signing the I9I4 labour treaty with Liberia, surrounded by the Gothic cathedral, the mission, the Governor's Palace, and the offices of the John Holt Company. The treaty was briefly renounced by Liberia in 1926 , and finally annulled in 1929, after which a fact-finding ILO

\footnotetext{
7. Bruno Latour, Reassembling the Social: An Introduction to Actor-Network-Theory (Oxford, 2005), p. 59. This network-theory direction is a response to the insistent cues of Frederick Cooper's critique of the term "global", found in its most programmatic form in Frederick Cooper, "Back to Work: Categories, Boundaries and Connections in the Study of Labour", in Peter Alexander and Rick Halpern (eds), Racializing Class, Classifying Race: Labour and Difference in Britain, the USA and Africa (London, 2000), pp. $213-232$, and idem, "Networks, Moral Discourse, and History", in Thomas Callaghy, Ronald Kassimir, and Robert Latham (eds), Intervention and Transnationalism in Africa: Global-Local Networks of Power (Cambridge, 200I), pp. 23-46.
} 


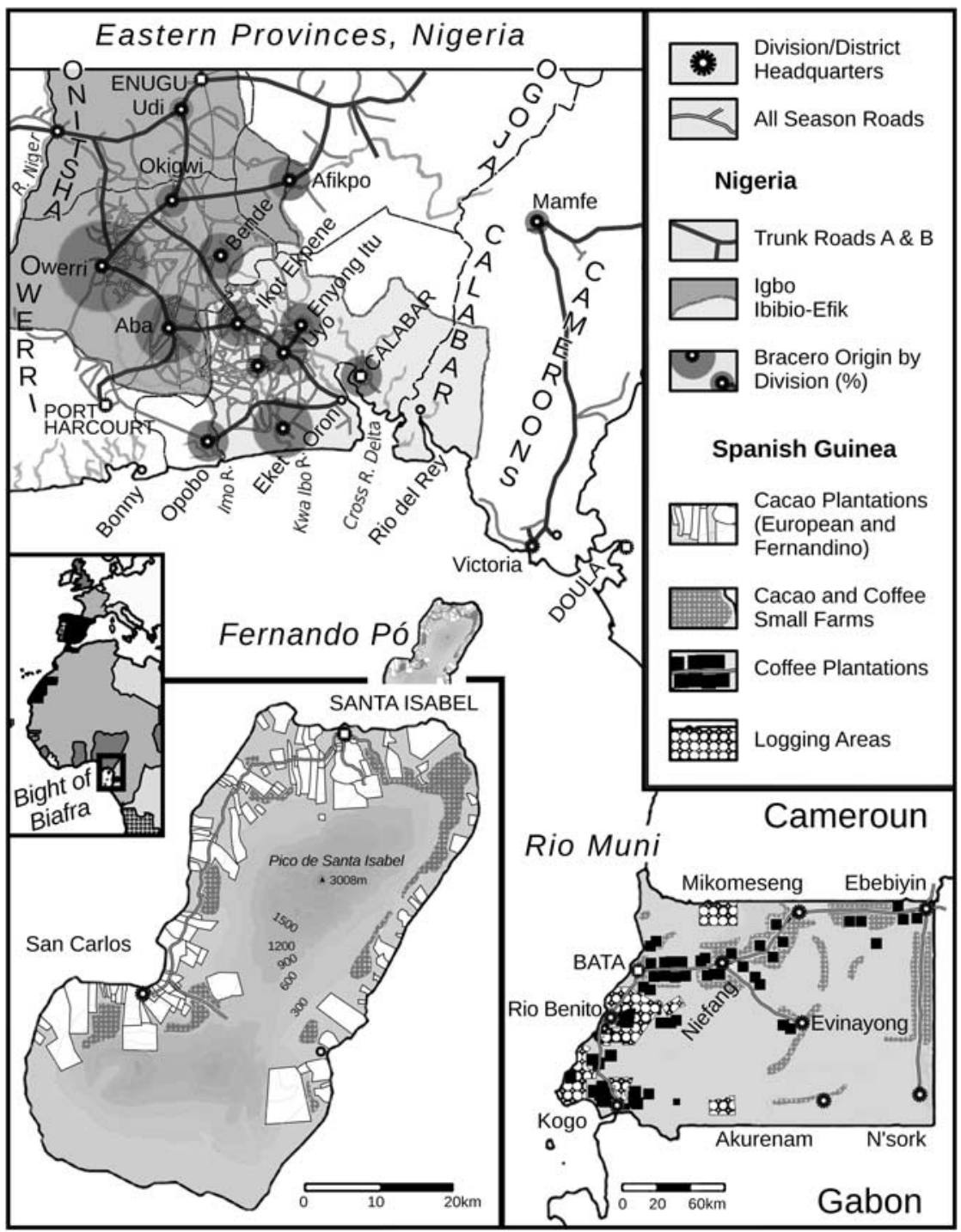

Figure I. Map of the Bight of Biafra in I940. For Nigeria all five eastern provinces, including the Cameroons, a British Mandated Territory, are visible. Each province was subdivided into several divisions, whose borders are not drawn, although their relevant headquarters are. The circles indicate the origin of Nigerian braceros by division. The road network is a good proxy for population density. For Fernando Pó, land use is to actual size. ${ }^{8}$

8. The map of Nigeria in 1940 is adapted from "A Ten-Year Plan of Development and Welfare for Nigeria”, National Archives of the UK, London: Public Record Office [hereafter, TNA, $\mathrm{PRO}], \mathrm{CO} 657 / 53$. The maps of Spanish Guinea are adapted from Jaime Nosti Nava, Notas 
commission discovered that contract workers had "been recruited under conditions of criminal compulsion scarcely distinguishable from slave raiding and slave trading". ${ }^{9}$ Liberia's first treaty retraction cut the plantation labour figures by half, and in response the new governor, General Miguel Nuñez del Prado, orchestrated the military occupation of Rio Muni.

Before 1926, Spanish control on the mainland was limited to the coastal towns and most of the roo European residents had been German factory shop owners and arms dealers who bought up hardwood, wild rubber, and ivory. In the years that followed, with prestación personal (corvée) in lieu of tax, some 500 kilometres of roads and bridges were built, dotted with garrisons of the colonial guard. At any given moment, up to 4,000 Fang were working unwaged on such public works, and the dictates of forced labour meant that people were shuffled off to the plantations by the colonial guards on any pretext of disobedience. ${ }^{10}$ Systematic disempowerment and induced indebtedness were also fostered by the colonial courts, who summarily distributed heavy fines or sentences of forced contract on Fernando Pó, so that during the three months approaching the harvest season in 1926 some 4,500 braceros and I,I8I accompanying and working women were sent there. ${ }^{\text {II }}$ Alongside such forced labour schemes, the aggravated labour scarcity on the island activated a private recruitment industry.

geográficas, físicas y económicas sobre los Territorios Españoles del Golfo de Guinea (Madrid, I942), pp. I20-I 22. Data on the origin of Nigerian braceros can be found in C.W. Michie, "Labour Conditions in Spanish Guinea" (28 February I94 I), TNA, PRO, FO 37I/26908. Jaime Nosti Nava, La agricultura en guinea española (Madrid, I955), p. I 53 , writes that "at least fifty per cent of contracted braceros are Ibo from Owerri". In I940 i 8 per cent of the island was under cultivation, 26,340 hectares or $7 \mathrm{I}$ per cent by Europeans, and 10,600 hectares or 29 per cent by Africans. There were some 270 cacao producers, I00 of whom did not employ migrant labour. See Günther Wolff, "Ein Beitrag zur Wirtschaft von Fernando Poo", Beiträge Zur Kolonialforschung, I (1942), pp. 93-I IO.

9. "Slavery Conditions in Liberia", New York Times, 27 October 1930. See the foundational work of Ibrahim Sundiata, From Slaving to Neoslavery: The Bight of Biafra and Fernando Po in the Era of Abolition, I827-1930 (Madison, WI, I996), pp. I17-I 22.

I०. Gustau Nerín, La última selva de España. Antropófagos, misioneros y guardias civiles: Crónica de la conquista de los Fang de la Guinea Española, I9I4-I930 (Madrid, 2010), p. 2 I 8. In the early twentieth century there were other forced labour schemes also subjecting the indigenous Bubi populations of Fernando Pó. See Gonzalo Sanz Casas, "Los finqueros y el uso del trabajo forzado en la agricultura colonial de la isla de Fernando Poo", Arxin d'Etnografia de Catalunya, 3 (1984), pp. I23-136; and Dolores Garcia Cantus's ongoing research. The small historical literature on Equatorial Guinea has focused almost exclusively on Fernando Pó and on the pre-1930 period.

I I. These women worked unwaged as cooks and cultivated food plots near plantations; GG to DGMC, I2 October 1926, C-81/07646. For indictments against the entire colonial institutional apparatus, see Curaduria to GG, 27 July 1932, C-8I/8 I25, E-4; Nerín, La viltima selva de Espana, p. 225. This is the only published work, beyond the very few sentences in other publications, dealing with labour issues in Rio Muni. It does not, however, cover the activities of the private recruiters. 


\section{Reclutadores, ganchos, and the money trail}

The start-up funds for the recruiter-entrepreneurs were easily provided by wealthy planters. The 10,000 tonnes of cacao exports were guaranteed to be sold in Spain at protectionist prices three times higher than the global market rate. ${ }^{\mathrm{I}}$ The existing harvest on the 36,000 hectares under cultivation already filled the subsidized cacao quota, and so all that was needed was to ring the labour-scarcity alarm and invoke the spectre of rotting crops and a bankrupt colony to perpetuate the exploitation of a just-in-time labour force that would be procured by any means necessary.

While a short-lived decree gave the Cámara Agrícola de Fernando Póo (Agricultural Chamber of Commerce, hereafter Cámara) a recruitment monopoly in Rio Muni that aimed "to avoid the recruitment of indigenous workers being bastardized and converted into an illicit trade, to the benefit of the recruiters", the allocation of any incoming labour by the Cámara suited only the so-called aristocratic planters, consisting of the early Catalan settlers, Spanish Cuban exiles, and the large corporate-owned plantations. The owners of the other major plantations were Spanish, Portuguese, German, and Fernandino - African immigrants originating from the nineteenth-century Portuguese Empire and British West Africa. Feeling their own hands were tied, the planters decided to force through the reintroduction of "FREE RECRUITMENT as the only solution". In December I927 the governor of Fernando Pó conceded and even extended "free recruitment to all territories outside the colony". ${ }^{13}$

The new logging lobby of Rio Muni entered the fray over labour in the late I920s by denouncing the deleterious effects of the island's recruiters, both in demographic terms and for its own commercial interests. There were fewer than I00,000 Fang in Rio Muni, and in 193080 per cent of the 5,000 annually contracted braceros were sent to the island. ${ }^{\mathrm{I} 4}$ That proportion was slowly being reversed as Fang workers much preferred

I2. William Gervase Clarence-Smith, "African and European Cocoa Producers on Fernando Póo, I 880 os to I9 Ios", Journal of African History, 35 (1994), pp. 179-199, 197; Jordi Sant Gisbert, "El modelo económico colonial y sus contradicciones: Fernando Poo (1900-1936)", AfroHispanic Review, 28 (2009), pp. 57-80, 65. In 1930 the Cámara blocked the granting of any further land concessions for almost two decades. For a broad overview, see Alicia Campos Serrano, "Colonia, derecho y territorio en el Golfo de Guinea: Tensiones del colonialismo español en el siglo XX", Quaderni Fiorentini, 33 (2005), pp I-27.

I3. Sebastian Llompart Aulet, Legislación del trabajo de los Territorios Españoles del Golfo de Guinea (Madrid, I946), p. I08; Finqueros to Cámara, 4 February 1927, AGA, C-81/08096, E-28; Llompart Aulet, Legislación del trabajo, p. I09. For an overview of the conflict see Gonzalo Sanz Casas, "Política colonial y organización del trabajo en la isla de Fernando Poo: 1880-1930" (Ph.D., University of Barcelona, 1983), pp. 24I-248; and in the local media “:Monopolio, No? ¿Exlusiva, Si?”, La Guinea Española, 25 March 1927.

I4. For the census tables and much more, written up by a wizard of statistics and founder of a Braudel-like structuralism in Spain, see Román Perpiñá Grau, De colonización y economia en la 
employment in the closer and better-paying expanding logging concessions of Rio Muni. With the final withdrawal of Liberian workers, the labour shortage on the island peaked. In the speculation and bidding wars for braceros, the commission paid by the cacao planters of Fernando Pó to the recruiters rose from 50 pesetas in 1926 to 500 and even to 800 pesetas in I93 I, of which 200-300 pesetas was pure profit. Considering that the average income of Europeans was 500 pesetas a month, that "margin of profit actively sustain[ed] a large army of intermediaries, direct and indirect, who by all possible means made sure they directed the workers to ensure the best agricultural interests of the island". Is

There were at least 60 European reclutadores operating at any one time. Professional recruiters could sign off up to roo braceros a month at the Curaduria (labour office) in Bata, whereas the part-timers could manage around io braceros. The latter group of reclutadores, more numerous, were start-up planters "who found in this activity the resources to cover the costs of running their coffee plantations" until the seedlings grew large enough to bear fruit, which would take at least three years. ${ }^{16}$ The first coffee plantations were dotted along the new road between Bata and Mikomeseng, and land concessions were more readily granted than private credit. In contrast to other European colonies, there were no immigration restrictions to Spanish Guinea to discourage - to use early twentieth-century census categories - "undesirable" Europeans of the "vicious" classes from settling.

During the I920s the colony experienced an economic boom and "served as a landfill site for Spaniards of the worst class who wanted to enrich themselves, quickly and easily", who wanted to "prosper and find a fortune". ${ }^{77}$ The reclutadores are described by Republican and Victorian authors as "callous, sleazy [and] spiritually barren", and, in one recruiter's own words, they were "merciless and criminal". ${ }^{18}$ Their methods were "legally prohibited but perfectly known". ${ }^{19}$ In Rio Muni the recruiters not

Guinea Española: Investigación, sobre el terreno, de la estructura y sistema de colonización en la Guinea Española (Barcelona, I945), p. IоI.

I 5. Cámara Bata to GG, i I August I93 I, AGA, C-8 I/8095, E-I7. In the late 1930s, 20 per cent of labour costs disappeared into recruiters' pockets, 20 per cent covered wages, 45 per cent went into imported food rations, and the remainder went for housing, sickness, death, and flight; Román Perpiñá Grau, "Mano de Obra Africana: Factor de coste colonial”, Cuadernos de Estudios Africanos (1947), pp. I27-I44, I 28.

16. Curador to GG, I6 June I93 I, C-8I/08125, E-2.

17. A. Victor Murray, The School in the Bush: A Critical Study of the Theory and Practice of Native Education in Africa (London, 1929), p. 25; Guillermo Cabanellas, ;Esclavos!: Notas sobre el África negra (Valencia, 1933), p. I9.

18. Curador to GG, I6 June I93I; Francisco Madrid, La Guinea incógnita: Vergüenza y escándalo colonial (Madrid, 1933), p. 89.

I9. GG to DGMC, 28 December 1935, AGA, C-8I/06867, E-5. 
only had free rein over Africans, but even established a mafia-like power of intimidation over European managers and administrators, even to the point of assaulting the labour officer if he dared question the true age of a bracero or the legitimacy of a contract's "signing". Some recruiters also operated illegal rackets to import alcohol and rifles, essential items needed by all the recruiters entering into negotiations with the local chiefs. ${ }^{20}$

The crucial interlocutors between all these mediators of the money trail were the ganchos (runners or literally "hooks"). Each reclutador operated with up to six ganchos, who were usually skilled labourers or employed as foremen in the Rio Muni plantations. These African intermediaries tended to be Kombe and Balenke who lived in the Bata area and had acted as porters in the first colonial expeditions. The coastal Ndowe groups had some trading and marital relations with the Fang, whose territory began at Niefang, although there were tensions between them, as after the end of the slave trade - which the Fang had largely evaded - there was a history of the Fang displacing the Ndowe further along the coast. ${ }^{2 \mathrm{I}}$

\section{Fang clan chiefs, regalos, and bridewealth}

The recruiters operated with two related tools that mediated their work of recruitment in a situation where there was no spontaneous market for voluntary labour. First, the regalo - literally "gift" but actually a full wage advance - used for the payment of bridewealth, and second, the payoff of the African labour intermediary. In the African social history literature that is less inclined to dwell on kinship, the practice of bridewealth and the figure of the collaborating chief are often tabooed and demonized and then treated as if they were expected to have operated by themselves. ${ }^{22}$ In such a detached functionalist view, the common commercial and missionary reading of "women being bought" and "chiefs selling the bachelors" takes over. Instead, with ethnographic patience and by taking the long detours and time lapses that the archive allows, it becomes possible to trace how labour recruitment was a product of a continuous thread of translations between wage advances, colonial

20. Madrid, La Guinea incógnita, p. 89; Gustau Nerín, Un Guardia Civil en la Selva (Barcelona, 2008), p. II 7 .

21. Muakuku Rondo Igambo, Conflictos étnicos y gobernabilidad: Guinea Ecuatorial (Barcelona, 2006), pp. 30-4I; Nosti Nava, Notas geográficas, pp. 51-60.

22. Even where the focus on the sites of wage labour has been dispersed to the home and hinterlands, as for example in chs 3 and 4 of Brown, We Were All Slaves, on recruitment in Eastern Nigeria, she does not dwell for long on the non-industrial ethnographic literature. The main works employed here, alongside the available sources, are Jane Guyer, Marginal Gains: Monetary Transactions in Atlantic Africa (Chicago, IL, 2004), pp. 27-49; Jonathan Parry and Maurice Bloch (eds), Money and the Morality of Exchange (Cambridge, 1989), pp. I-29. 
currencies, monetized bride-prices, the colonial state, and chiefly accumulation. In non-coastal Equatorial Africa it

[...] was not only a calculation and political power that created the spatial geography of exchange but also the ideology of transformation that undergirded it. The capacity to define, institutionalize, take advantage of, technically control, and symbolically represent conversions is at the heart of the extensive regional transaction systems that every autonomous polity built up in the stepwise relations that connected the interior to the changing currency flows of the great trade routes. ${ }^{23}$

Of course, such conversions or translations, tightly binding together money, gender, and power across different polities, were not always indispensable for labour recruitment. With state-directed forced labour, non-dialectical violence worked. To be sure, the private recruiters managed to break into the scene only after two sweeping acts of foundational colonial violence, namely military pacification and the imposition of a new colonial currency as a measure of value. Alongside the ongoing military invasion, recruiters often dressed up in uniform or otherwise made use of the aura of intimidation derived from systematic police brutality to hoax and coax entire villages. Alongside the imperial occupation, the Spanish colonial authorities prohibited the use of previous currencies. A proletarianizing poll tax was not yet in place, but the peseta coin came to be quickly translated by the Fang for the purpose of bridewealth payments. ${ }^{24}$

In several sources the ganchos and the reclutadores unanimously describe the process of recruitment in formulaic terms. They would drive along the Bata to Ebebiyin Road, on or near to which the Fang population had been told to relocate their "villages, strung out like beads upon the arteries of commerce by the colonial administration". ${ }^{25}$ The ganchos would inquire in a mix of Fang and Pidgin English if any men could be supplied. The resident chief would categorically answer in the negative until a sufficient combination of cash and goods were promised - the expected rate was 100 pesetas - and would include items such as salt,

23. Guyer, Marginal Gains, p. 39. For a similar stepwise analysis of the emergence of a labour market in a nearby logging industry, see Christopher Gray and François Ngolet, "Lambaréné, Okoumé and the Transformation of Labor along the Middle Ogooué (Gabon), 1870-1945", Journal of African History, 40 (1999), pp. 87-107.

24. Fernando Muakuku Rondo Igambo, Guinea Ecuatorial: De la esclavitud colonial a la dictadura nguemista (Madrid, 2000) p. 48; Nerín, La última selva de España, pp. 225, 249; Guyer, Marginal Gains, p. 30. In the early twentieth century currencies included iron arrowheads, tobacco, guns, and German and French money.

25. James Fernandez, "Fang Representations under Acculturation", in Philip D. Curtin (ed.), Africa and the West: Intellectual Responses to European Culture (Madison, WI, 1974), pp. 3-48, I7. 
tobacco, textiles, a bottle of brandy or wine, or even a rifle. To seal the deal, a 300 peseta on-the-spot regalo was advanced to anyone signing up for contract labour. The recruiters negotiated and spoke in commercial situations and terms, and in the sources they hardly reflect on how they unwittingly mobilized labour through the extensive mediations of currencies and polygamist clan chiefs.

Fortunately, there is a subaltern reflection in a singular interview transcript dated July i93 I. The first republican labour officer, branded a Bolshevik by the planters, took it upon himself to ask each of the I65 braceros who were waiting at his Curaduria for the steamship to Santa Isabel how they had been recruited. The majority said they had come because of the 300-peseta regalo for comprar mujer, the adopted Hispanicized term for bridewealth, or literally "buy wife", which was needed to fund a marriage either for themselves or a brother, or required to settle the debt of a divorced sister or mother. ${ }^{26}$ Of those interviewed, about onequarter admitted to being French subjects, who had then illegally crossed the border with a gancho as they were attracted to the lower bride-prices in Rio Muni. ${ }^{27}$

Marriage was strictly exogamic to the patrilineal descent group or clan. A series of intermarrying clans would tend to form a grouping, such as the Ntumu Fang who lived in the northern half of Rio Muni, southern Cameroon, and the Woleu-Ntem province of Gabon. ${ }^{28}$ While at that time there was no overarching authority between clans, nor any institution of slavery, there was considerable economic inequality and intense prestige competition between clans, and both were heightened by the influx of recruiters. For any important social events between Fang clans, men engaged in a performative bilaba, a milder type of potlatch, or "total prestation", that required an exorbitant but "honourable level" of giftgiving by the hosts. ${ }^{29}$

26. Curaduria Bata, July I93 I, AGA C-8I/8I 25 E-2; of the braceros in the group 20 per cent were under the age of fifteen.

27. There were several thousand French-African subjects in Spanish Guinea. France had denounced illegal recruitment before the League of Nations almost annually between 1929 and 1933, and encroaching ganchos were given ten-year prison sentences in Duala and Libreville; GG to DGMC, 28 December 1935, AGA C-81/06867, E-5. See Maurice Mveng, "Note sur l'emigration des Camerounais à Fernando Po entre les deux guerres mondiales", Abbia, 23 (1969), pp. 35-43.

28. Clans, made up of discontinuous family-based hamlets, were of highly variable size but tended to fall into the three-figure range. The Ntumu Fang are a subgroup of the Fang, who in turn are subcategorized into the broader linguistically defined Beti-Pahuin peoples. See Wikipedia or Georges Balandier, The Sociology of Black Africa: Social Dynamics in Central Africa (New York, 1970); Augusto Panyella, Esquema de etnologia de los fang ntumu de la Guinea Española (Madrid, I959).

29. Nerín, Un guardia civil en la selva, pp. 90-96; Guyer, Marginal Gains, pp. 40-4I; Balandier, The Sociology of Black Africa, p. 28. 
The most substantial way to increase food production and the network of alliances was through, in Lévi-Straussian terms, the exchange of women. Marriage was an exchange of female labour and reproductive potential. A son without a sister could not have a wife, and wives worked more than sisters and much more than men..$^{3 \circ}$ Paying the bride-price was not an act of buying, as a wife could usually neither be "sold on" nor converted into common commodities. Also, a married woman remained strongly linked to her lineage and, as solidarity in kinship was extended to the entire lineage and clan, should a woman become divorced the money to reimburse the bridewealth would be acquired by one of her brothers. This was the situation for one-third of the respondents.

Divorce rates were on the increase, as due to the rising bride-prices remarriage was a more lucrative option for a wife-giving clan. It tended to be only the nkukuma or "clan chief" - a recent term for the title, meaning "wealthy" in Fang - who could afford the new bride-price and who would accumulate wives. When the gancho arrived, the nkukuma would either marry off wives or collect the outstanding debt of another clan who had already received one of his wives, effectively leaving him with the 300-peseta regalo of the recruit in addition to the roo-peseta bonus. That was the case with half the respondents, most of whom also said that their brides had been accompanied to their patrilocal villages by one of her new in-laws, as otherwise they feared she would suffer harassment or be tempted to remain on Fernando Pó doing alternative work. Polygamy was not a matter of increasing the labour input of the village economy, for the increase in the practice as well as the act of "selling on" divorced wives were innovations boosted by the recruiting process. ${ }^{3 \mathrm{I}}$

In terms of the usual categories of labour mobilization, rather than opposing them or stipulating a hidden "articulation" between them - that is to say between the domestic mode of production or acquiring labour through marriage, and the capitalist or contractual wage relationship both can be seen as a continuous translation between non-equivalent

30. In the basic stereotype, women would work the subsistence farms and market goods, while men would help in the yearly slash-and-burning of a new plot, raise domestic animals, and fish or hunt; Joaquín Mbana, Brujería fang en Guinea Ecuatorial (Madrid, 2004), pp. I3-24; Nosti Nava, Notas geográficas, p. 5 I. Men also supervised children, engaged in craft metalworking, and most famously in sculpting (and selling) biere, statuettes that guarded the ancestral bones and which populate all ethnographic museums in Europe and even inspired Picasso's first cubist painting. See Guyer, Marginal Gains, p. 45, who adds that "to the Fang, the real value was in the bones, not the statues".

3I. Jack Goody, "Polygyny, Economy and the Role of Women", in idem (ed.), The Character of Kinship (Cambridge, 1974), pp. 175-190. This procedure, in which the chief controls the circulation of women to mobilize a labour force for capital, forms a basis of the articulation of modes of production theory in anthropology. See Claude Meillassoux, Femmes, Greniers et Capitaux (Paris, 1975). 
bridewealth and equivalent abstract labour, standardized through quantifiable colonial money across cultural norms. Such translations, which drove the recruitment of remunerated unskilled braceros, in turn depended on the monetization by legislative fiat of the reproduction of Fang socio-economic life. With the sudden prohibition of other currencies and the forced introduction of the peseta, within just a few years the brideprice had risen from about 50 pesetas to 300 in 1929, at which point this price became fixed by government decree. However, as one of the recruits told the labour officer, the 300 pesetas was the bride-price only for a "divorced woman belonging to a chief". Like several others among those interviewed, the recruit had given the regalo to his family to save for the 500-peseta bride-price for a wife acquired directly from an almost extortionist future father-in-law. The state's monetary policy and "price regulation" was crucial to speeding up the regalo method of recruitment as it stabilized both the powerful intermediary position of the chiefs and the burgeoning labour costs for the employer.

\section{Trickery, the work contract, and fines}

The ganchos and braceros interviewed also revealed some of the tricks of the reclutadores, on whose actions the somewhat spineless backbone of the recruitment system was based. Ganchos were told to pretend that they were recruiting for the logging industry in Rio Muni or otherwise to claim falsely that they were working for a reputable planter in a "good area" located near a town and with no sleeping sickness. The most appallingly deceitful method employed by the recruiters was to refer to the 300-peseta wage advance as a regalo. Over half the recruits were induced to believe that the regalo was literally a gift, while to those who knew full well that the regalo would be deducted from their pay the reclutadores insisted that due to the scarcity of labour it was now indeed a "gift". The wages for a bracero on the island were 20 pesetas a month, one-half of which was paid monthly, while the remaining 240 pesetas were released at the end of a two-year contract. If the braceros had not been saving their monthly wages, then at the expiry of the contract the planters would force them to renew their contract to repay the remaining 60 of the 300 -peseta regalo. ${ }^{32}$

An employer could be chosen or changed only in the rarest of cases. To top it off, the working day was measured by a foreman's estimate of "a day's work". Piecework was a managerial strategy that served to replace constant supervision with occasional performative threats and actual assaults that would often lead to I 2 -hour workdays shot through

32. Curaduria to GG, 28 November $1933, \mathrm{C}-8 \mathrm{I} / 08$ I26, E-21. In the case cited, the Labour Officer refused to renew a debt-bondage-based contract, but the planter was outraged enough to make it clear that this extortion was usual. 
with violence. ${ }^{33}$ Those features of the labour contract led to misery among the workforce and sustained the high fees of the recruiters. The republican labour officer in Rio Muni knew that the labour scarcity was not a matter of some sort of conflicting African work ethic, but rather that it was the paltry wages and the constant deductions from them, as well as the isolating and brutalizing contract conditions, that kept potential workers at bay. Colonial "laziness" tropes were popular merely in the colonial metropole and the media, and were only intermittently appealed to to legitimize violent exploitation.

Privatized recruitment in Rio Muni wound down in the final years of the republican period. Fines were finally dealt out to reclutadores for violations of the labour code (that since I9I 2 had prohibited payments to chiefs), and for causing speculation by selling on individuals already recruited. The industry's profit margin was slashed, and while the recruiters and their emissaries and accomplices disbanded, the highest bidders in Fernando Pó looked elsewhere. In just a few years the number of braceros contracted to Fernando Pó's plantations from Bata dropped to fewer than seventy, while the desertion rate among Fang labourers in Rio Muni increased. ${ }^{34}$ Eventually the regalo wage-recruitment system was abolished altogether because of the escalation in cases of "serial" recruits - those who continually went to different recruiters or employers to receive the regalo only to disappear again..$^{35}$

The republicans sought to "humanize recruitment and suppress intermediaries", and to "attract rather than capture" wage labour, but in order to "stimulate voluntary and spontaneous immigration", bridges needed to be built for a surplus proletariat to cross closely policed imperial borders. ${ }^{36}$ Those bridges were conveniently constructed by an ensemble of Nigerian recruiters, as an outgrowth of stratified social groups and the

33. There is much evidence of this in the archives, and a good quarter of the planters and/or their overseers could be described as brutal. For fines and working conditions see AGA, C-8 I/ 08 I 28, E-I 4; C-8I/08 I 29 E-2. On the anomalous position of Fernando Pó in West and Central African colonial history, in terms of the long two-year labour contracts and the extremely harsh vagrancy laws, see William Gervase Clarence-Smith, "Cocoa Plantations and Coerced Labor in the Gulf of Guinea, I870-1914”, in Martin Klein (ed.), Breaking the Chains: Slavery, Bondage and Emancipation in Modern Africa and Asia (Madison, WI, 1993), pp. I 50-170.

34. Perpiñá Grau, "Mano de Obra Africana", p. I29. The figure in I94I was very high; more than 20 per cent fled once they had received the regalo; idem, De colonización y economia, p. 365. The I930s saw the complex disintegration/reinvention of Fang political life through the alar ayong or "pan-clan" anti-colonial movement and the famous, drug-fuelled reformative bwiti cult popular in the logging labour camps. See James Fernandez, "The Affirmation of Things Past: Alar Ayong and Bwiti as Movements of Protest in Central and Northern Gabon", in Robert Rotberg and Ali A. Mazrui (eds), Protest and Power in Black Africa (New York, 1970), pp. 427-457.

35. Cámara Bata to GG, 30 July 1946, AGA, C-8I/08 I30, E-I.

36. GG, I October 1934, AGA, C-8I/08 I26, E-I; Curador to GG, I6 June I93 I; DGMC to GG, 4 June 1932, AGA, C-81/06415, E-2. 
continuing decline of the colonial economy of south-eastern Nigeria during the long decade of the I930s, from the Great Depression until the end of World War II.

\section{THE NIGERIAN CONNECTION, 1935-1945}

From the Calabar coastline the silhouette of the volcanic peak of Fernando Pó is clearly discernible on the horizon. The Nigerian recruiters navigating the stretch to the island were a motley crew of former labourers and traders, and professionalized gangs run by canoe-owning coastal merchants. While the former continuously slipped in and out of small-scale recruitment, it was the latter, the commercial elite of Calabar Province, who paved the way for this clandestine sea lane across the bay, on both steamers and canoes. While the traffic on such different vessels was simultaneous, there was a clear break during the Spanish Civil War when the numbers of braceros arriving on colonial ferry boats dried up, only to rise exponentially on the tide of large sea-going canoes. In the post-Spanish-Civil-War section below, the social structures within which the Nigerian recruiters operated are contrasted, specifically between the kinship-based networks of Igbo traders and former labourers and the patronage-based Efik wards in Calabar and the caste-class axes of Ekpe, their "secret society".

Why both those groups of recruiters threw themselves at the opportunity afforded by Fernando Pós planters can be understood only by constant reference to the material consequences of the solidification of British colonial rule and the palm oil depression, that is, the development of a transport infrastructure which reversed the fortunes of canoe-owning middlemen as well as the "remorseless decline" of prices for palm products offered to farmers by the European import-export factories. ${ }^{37}$ Awaiting them at the Curaduria in Santa Isabel were guaranteed payments of between 500 and 800 pesetas (or $£_{1} \circ$ to $\mathfrak{£}_{1} 6$ ) per bracero delivered. ${ }^{38}$ Most of the commission being profit, their activity was lucrative indeed; even the lower figure was the equivalent of around 5 months' work as an individual trader or a year's work on a plantation. In 1935 there were 5,000 Nigerians on the island, one-half of whom were braceros. ${ }^{39}$ By 1940 some I0,000 Nigerians were under contract

37. Susan Martin, Palm Oil and Protest: An Economic History of the Ngwa Region, SouthEastern Nigeria, I800-I980 (Cambridge, I988), p. 88. Martin deduces (p. I I9) that in I933 palm oil was worth only i7 per cent of its barter terms of trade levels of I9I 2 and that Eastern Nigeria was in a long depression between 1914 and 1945.

38. This was double the rate of recruiting agencies operating in other African colonies; see Orde-Browne, Labour Conditions in West Africa, p. I I. For the largest recruitment treaty, in the early i 930 s the Union of South Africa paid the Portuguese Empire $£ 5$ per head for almost I00,000 labourers annually for I 2 -month contracts.

39. Nosti Nava, Notas geográficas, p. 20. Census data for the island's resident Africans in 1936: Bubi or Fernandino, 9,348; Rio Muni, 6,800; Nigeria, 4,819; French Cameroon, 4,200; 
in Spanish Guinea, a figure that had doubled by the final year of World War II. In those years, during the period of tax collection in Nigeria, coinciding with the cacao harvest and the canoe season between October and March, the number of new contracts exceeded I,000 per month. ${ }^{\circ}$

Including family members and other professions, two-thirds of the 40,000 residents on Fernando Pó were Nigerians, who for the most part had arrived outside the purview of the British colonial authorities, either with the help or through the deceit of recruiters. ${ }^{4 \mathrm{I}}$ The displacement of mostly unmarried braceros was accompanied by trafficking in sex workers. For many women departing under the guise of a wife or daughter it was "not difficult to imagine their ultimate occupation in Spanish territory". ${ }^{42}$ Fernando Pó was a very male-centric place, with almost 80 per cent of West African and European immigrants being men, whose hetero- and homo-socialities and sexualities were quite at odds with domestic or missionary moralities. ${ }^{43}$

\section{Ferry boats, bribes, and papers}

From I90I on it was forbidden for British West Africans to take up work as plantation labourers in Spanish Guinea. The first Nigerian Labour Ordinance in 1929 had included severe penalties for "unlicensed recruiting for foreign territories", by which was meant Fernando Pó. ${ }^{44}$ In

São Tomé, 209; Liberia, I75; Sierra Leone, I 55; Annobon and Corisco, I46. At that point most non-Spanish African migrants were skilled labourers or traders of all sorts rather than braceros, and were regarded with some hostility for not making themselves "useful" to the plantation economy. See GG to DGMC, I 2 June 1933, AGA, C-8 I/06467 E-19; "Hospitalidad Excesiva”, El Defensor de Guinea, 2 November 1933.

40. British Consul to GG, io July 1946, AGA, C-8 I/08 I 30, E-1.

4I. Akinjide Osuntokun, Equatorial Guinea-Nigerian Relations: The Diplomacy of Labour (Ibadan, 1978), pp. 36-40. This book is the only published work dealing even partially with this period, but Osuntokun had no access to the Spanish archives. For I940s census data, see Sebastian Llompart Aulet, Anuario estadistico de los Territorios Españoles del Golfo de Guinea (Madrid, 1945), p. 195; and Wolff, "Ein Beitrag zur Wirtschaft von Fernando Poo", p. I08. 42. Michie, "Labour Conditions in Spanish Guinea" (28 February I94I). The quotation is from a 1943 newspaper article cited in David Pratten, The Man-Leopard Murders: History and Society in Colonial Nigeria (Edinburgh, 2007), pp. I66-167. Calabar was the central recruiting ground for prostitution networks that spanned Nigeria and British West Africa; see Laurent Fouchard, "Urban Poverty, Urban Crime and Crime Control: The Lagos and Ibadan Cases, 1929-1945", in Steven J. Salm and Toyin Falola (eds), African Urban Spaces in Historical Perspective (Rochester, NY, 2009), pp. 29I-320, 300.

43. Llompart Aulet, Anuario estadistico, p. 29. For so-called "unnatural acts" between men on the plantations, see British Embassy to Ministerio de Asuntos Exteriores, 5 December 1945, Archivos del Ministerio de Asuntos Exteriores, Madrid, Archivo Renovado [herafter, AMAE], R 2370, E-I I.

44. David Aworawo, "Decisive Thaw: The Changing Pattern of Relations between Nigeria and Equatorial Guinea, 1980-2005", Journal of International and Global Studies, I (2010), pp. 89-109, 95. The nine prosecutions in 1939 of illegal recruiters by the Calabar courts rose to over 100 in 194I; British Consul to GG, I0 July I946, AGA, C-8г/08 I30, E-I. 
spite of the $£_{5} 00$ fines or 5 years' imprisonment, the illegal recruiters were adept at outmanoeuvring the half-hearted attempts to police them. In the early i 930 s the role of the recruiters was to act as a "conductor of the recruits through the network spread by the police in Nigeria to prevent their emigration", and they were akin to "publicity agents for the island, not so much misrepresenting the conditions on the island as failing to mention that employment conditions were unlike Nigeria". ${ }^{45}$ The recruiters paid for ferry tickets, bribes, the necessary counterfeit paperwork, and other travel expenses, but the recruits were "made to sign an I.O.U. acknowledging that should they fail to take up contract on the island they would owe three pounds to the recruiter". ${ }^{46}$ Hundreds of new recruits arrived every month on the ferry boats, but the IOU made backtracking on arrival prohibitively expensive for them. Furthermore, being an immigrant without a work contract on the island was not a legal option. In 1933 vagrancy laws, targeting unemployed and self-employed migrants, established that those who did not "seek work within is days" or pay for their own deportation should be sent to the "disciplinary brigades" of the prisons and used as labour for public works. ${ }^{47}$

In 1934 a petition signed by seventeen "Ibibio Boys" entitled "THE ATROCITIES OF THE SPANISH IN FERNANDO POO” reached the British Consul in Santa Isabel. The Consul visited the plantation from which the complaint had emerged and after talking to the Nigerian braceros he concluded that "their chief grievance seemed to me to be that they had been tricked by the recruiters into farm work against their wishes [... and expectation] to being apprenticed to some trade, and that they had no share in the bonus paid by their employer to the recruiters". ${ }^{8}$ The first public alarm was raised in a letter to the editor in a 1936 issue of the important journal the West African Review:

British Subjects in Africa have known freedom from slavery for nearly one hundred years. We have seen Abyssinia and Liberia under reprimand for this offence, yet little or nothing has been said about the trade still carried on by Spain in her territories in the Gulf of Guinea. [...] The unlawful activities of people employed by Spain to recruit men chiefly in Calabar and other parts of

45. T. Farley Smith, "Report on Employment of Nigerian Labour in Fernando Poo. Submitted after a visit lasting from June sth to July 4th, I939", 2 I September 1939, TNA, PRO, FO 37I/ 23171 .

46. A.E. Yapp, "Report On Employment of British Coloured Labour in Fernando Po, as the Result of a Visit made August 29th-September ist, I936", i7 September 1936, TNA, PRO, CO $554 / 105 / 3$. An IOU, or "I Owe You", is an informal document acknowledging debt.

47. Llompart Aulet, Legislación del trabajo, p. I3 I. For the creation of this law, see GG, "Extranjeros en la Colonia", AGA, C-8 1/08 I 56, E-6.

48. British Vice-Consul to the Resident of Calabar Province, I3 September 1934, TNA, PRO, $\mathrm{FO} 458 / \mathrm{I} 26$. 
Nigeria $[\ldots]$ is more than obvious in Fernando Poo, where there are thousands of Ibos. [...] Cannot something be done to stop this illegal traffic in human cargoes?

The letter was signed anonymously by "Salvador" (Saviour), but the author was quickly arrested in Santa Isabel after a visiting correspondent from the Nigerian Daily Times "Mr. J.S. Olu Georg who when a special degree method was used on him, disclosed the name of the writer of the article". ${ }^{49}$ Salvador was revealed to be Samuel Babington Macaulay, a Fernandino from Lagos but born on the island, and from prison he somehow managed to get hold of a typewriter and in a letter to the British Vice-Consul claimed that "the boys thus recruited I am cocksure are brought here through the aid of the falsified permits manufactured one way or the other by the RECRUITERS". ${ }^{\circ}$

The British Consul General for the region was then sent on an investigative tour of the island. The British captain of the steamer that took him there showed him forged police permits, which acted as passports for legitimate traders to embark on ships destined for Santa Isabel. The forgeries "were very clever ones but not clever enough to deceive the Captain who pointed out three slight errors in it". While on that day the recruiter and the eighteen recruits "hastily and unceremoniously left the ship", the British captain confessed that:

[...] the temptation held out to a [ship's] Master was so alluring that even he might fail. [The Captain] said if he wished to work with the recruiters he could clear a roo pounds every crossing. The passage money he said to Fernando Po was Io/- [shillings]: any recruiter would readily pay him an extra $10 /-$ or more per head if he agreed to accept the boys illegally. He could carry 200 each passage. $^{\text {s }}$

In Calabar "vendors of second hand and forged passports made a lucrative income".52 As for acquiring original permits, two recruiters from

49. Salvador, "Slavery in Spanish Guinea", West African Review, May 1936; "Sensational Arrest at Fernando Po", Sierra Leone Daily Mail, i6 September 1936. The Salvador piece was reprinted with a commentary by the media mogul and first president of Nigeria Nnamdi Azikiwe, who noted ironically, "Let Fernando Po's inhumanity be spotlighted. Let Spain explain its slavery. But then Spain is a Colonial Power and a European State at that, which explains a lot"; Zik, "Inside Stuff: Fernando Po", The African Morning Post, 27 May 1936.

50. Samuel Babington Macaulay to British Vice-Consul, 30 August I936, TNA, PRO FO 458 / I 27.

51. Yapp, "Report On Employment of British Coloured Labour", 17 September 1936. 20 shillings $=\mathfrak{E}_{\mathrm{I}}$. Similar observations can be found in W. Benson, "The Fernando Po Labour Demand", February i 936, TNA, PRO, CO $554 / 105 / 3$. See also W. Benson, "Some International Features of African Labour Problems”, International Labour Review, 39 (1939), pp. 34-45. 52. Rev. Ewart Shepherd, "Nigerian Labourers in Fernando Po: Dr. Haden Guest Misinformed? Allegations of Slavery Cannot Be Substantiated”, West Africa, i 9 May 1939. 
Eket "boasted [to the Consul] that they will never have trouble in Calabar as they pay the Native Police Inspector WULOBI (or some such name) I pound per head". 53 The dealers in paperwork also bought up and resold "permits of return", issued by the British Consulate in Santa Isabel, which enabled new recruits to travel under the false names of those leaving the island with no intention of returning. ${ }^{54}$ The Spanish colonial state was "lazy", and while the British attempted to regulate labour recruitment by generating paperwork, documents were quickly forged, circulated, or evaded by a series of mediators, to the detriment of a significant proportion of Nigerian recruits, who while arriving voluntarily were not expecting to encounter the desolate drudgery of the bracero.

\section{The Spanish Civil War and the palm oil belt}

Fernando Pó was overrun by Francoist mutineers in July 1936, the first month of the Spanish Civil War. Within the next two years it was "impossible to bring braceros from Calabar" as recruiters ceased their operations since all foreign exchange was to be rerouted to Spain for the fascist front. ${ }^{55}$ During those years braceros were regularly forced to renew their contracts as they were told by the Curaduria that "We got no money, You better go back to work - contract for two more years - we will not let you walk in the streets' - or something to this effect". ${ }^{56}$ The export of all currency was suddenly prohibited and recruiters or traders leaving the island were thoroughly harassed at customs and subject to intrusive searches. Even though their money was well hidden, small fortunes were confiscated by the Spanish nationalists. ${ }^{57}$ Traders stopped trading and as a result the British ferry lines cut off their services to Santa Isabel, a withdrawal that "presented the canoe owners with a practical [transport] monopoly, of which they have not been slow to take advantage". ${ }^{8}$ For non-Spanish recruiters and braceros, half of their fee and wage was paid in British money, and some $£_{2,000}$ a month were finally earmarked for the Curaduria in Santa Isabel in 1938. The recruiting networks sprung back, and profits rose because there was no

53. British Vice-Consul to the Resident of Calabar Province, I3 September I934.

54. Only 50 "permits of return" were issued in 1936, and by 1939 the British Vice-Consul was issuing I 50 a month; British Vice-Consul to the Resident of Calabar Province, I 4 January I939, TNA, PRO, CO, 554/II9/5.

55. Cámara to GG, i April I937, C-8 I/08 I 29, E-2; Junta de Importación y Exportación to GG, 22 May 1937, AGA, C-8I/08056, E-ı. For a thorough overview see William Gervase ClarenceSmith, "The Impact of the Spanish Civil War and the Second World War on Portuguese and Spanish Africa", Journal of African History, 26 (1985), pp. 309-326.

56. Yapp, "Report On Employment of British Coloured Labour", i7 September 1936. As a result of the Liberia Treaty and to make immigration more attractive, the Labour Code stipulated that half the wages of foreign workers were to be paid in sterling.

57. British Vice-Consul to British Legation, Monrovia, i July i938, TNA, PRO, CO 554/I I $4 / 10$. 58. Michie, "Labour Conditions in Spanish Guinea" (28 February I94I). 
expensive paperwork to pay for on the canoes and because wartime Spanish monetary policy had intensified the labour shortage.

The recruiting fee represented a clear leap in income and social mobility, which is why "every labourer who has completed his first term of contract [was] a potential recruiter. Frequently also the older hands [on the plantations were] given advances in sterling to pay for recruiting expenses". ${ }^{59}$ Back in Nigeria, recruitment paths were shaped through kinship ties and the ethnically redefined immigrant associations proliferating in urban areas. These "home-town" associations served many extended community needs. They were always, for example, the first port of call for new arrivals seeking employment opportunities. ${ }^{6}$

Almost all recruits were Owerri Igbo or Southern Ibibio from the "palm oil belt" provinces, where land scarcity was acute and the population density was one of the highest in Africa. In the I930s Calabar Province contained a little over I million people, while some 2 million lived in Owerri and subsistence levels were nowhere very high. Palm, and increasingly cassava, the main cash crops, were grown in between food crops on family farms. In colonial cartographic categories, in some of the districts of eastern Nigeria there were over roo "taxable males per square mile", as opposed to approximately a single I per square mile in Rio Muni. ${ }^{6}$

The reasons for migration are portrayed in the general and regionally specific literature, as well as often by migrants themselves, around two poles, a liberal and ethnographic narrative and a Marxist and materialist storyline. On the one hand, there is the genre of Wanderlust, of adventurous youth propping up exchange and prestige value with the eventual aim to "deproletarianize" and reintegrate into home communities, but at a step up. On the other hand, there are the constant reminders of the struggle of the poverty-stricken upon whom responsibility falls for covering payments such as taxes and bridewealth. ${ }^{62}$ After the invasion by

59. Ibid.; Casa Drumen to GG, 2 I October 1938, C-8I/08 I26 E-I.

60. W.T. Morrill, "Immigrants and Associations: The Ibo in Twentieth Century Calabar", Comparative Studies in Society and History, 5 (1963), pp. 424-448; Richard Henderson, "Generalized Cultures and Evolutionary Adaptability: A Comparison of Urban Efik and Ibo in Nigeria”, Ethnology, s (1966), pp. 365-391; Howard Wolpe, Urban Politics in Nigeria: A Study of Port Harcourt (Berkeley, CA, I974), pp. 56-81; Brown, We Were All Slaves, pp. I82-187.

61. Martin, Palm Oil and Protest, pp. 90-96. For the overlap in recruitment in Owerri and Bende for the Enugu mines, which in this period employed some 2,400 workers, see Brown, We Were All Slaves, pp. I5 5 -160.

62. Segun Osoba, "The Phenomenon of Labour Migration in the Era of British Colonial Rule: A Neglected Aspect of Nigeria's Social History”, Journal of the Historical Society of Nigeria, 4 (1969), pp. 51 5-538, 524. See the editor's introduction in Samir Amin (ed.), Modern Migrations in Western Africa (Oxford, 1974), pp. 93-1 18, and Aderanti Adepoju (ed.), Internal Migration in Nigeria (Ife, 1976). For oral history see Chima Korieh, The Land Has Changed: History, Society and Gender in Colonial Eastern Nigeria (Calgary, AB, 2010), pp. 268-282. 
British colonial armies, the interwar period in Nigeria witnessed political stabilization and a massive pauperization that enabled an increase in mobility. Those who had to look outside the village economy were often younger sons, who would be the last to receive their disappearing share of land and whose bride-price could no longer be afforded as it had risen to as much as $£_{25}$ in some Igbo areas. ${ }^{63}$ The internal Igbo diaspora of colonial Nigeria was enormous, numbering in the millions, and to the long list of tenant farms, mines, trades, administrative, and urban jobs we should append Fernando Pó. It should be noted that the cumulative extent of migration from the eastern provinces, on the rise until the I970s, has largely been forgotten.

The Igbo recruiters came in much smaller groups than the more QJ;professionalized Calabar recruiters, and in the many testimonies of Igbo recruits available in the archives most said they had come "with a relative". ${ }^{64}$ That would mean someone from the same village group, although if an individual had already worked elsewhere in Nigeria and been perceived as a "foreigner" kinship terms would encompass much larger groupings. Migrants would usually have to walk, but with the recruiter's advanced fee, buses, trains, and canoes were used to reach Oron, from where the ocean-going canoes would sail in convoys to the island. Each canoe could seat up to forty people, including the ten paddlers, and carry several tons of contraband goods. The logistics of this traffic were managed almost exclusively by the Efik of the Cross River Delta. ${ }^{65}$

\section{The Efik recruiters and the towns of Calabar}

While the recruiters were setting up their trade, the governor generals, the Spanish embassies, and the Cámara initiated, but unsuccessfully, labour treaties intended to bring indentured labour from India (1928, I947), China (1928), Indonesia (I928), Morocco (I929), Romania (I929), São Tomé (1929, I93I), Cameroon (1934), Congo (1945), Haiti (1934, I949), from Liberia again (1949), and persistently from Angola (1930, 1939, 1945, 1952). ${ }^{66}$ Personalized recruitment was more reliable and cheaper

63. Martin, Palm Oil and Protest, p. 100.

64. In the Curaduria and police files at AGA there are over Ioo witness statements about numerous incidents in which Nigerian labourers were always initially asked to give details of their route and arrival.

65. Michie, "Labour Conditions in Spanish Guinea" (28 February I94I). The journey took thirty-six hours. Oron was a small fishing village that became an important trading centre, with local fishermen selling many large ocean-going canoes; Ekong E. Ekong, Sociology of the Ibibio: A Study of Social Organization and Change (Ibadan, I983), p. 92.

66. Most of these far-fetched plans were false starts, while others crumbled, for numerous reasons, at the outset or after being signed. The archive is filled with un-histories of a standardized global indentured labour market. Even until the I960s, Spanish Guinea was desperate 
than the lump sums prescribed by indentured labour treaties. Already, in the early i930s, the Fernandino R. Barleycorn had a regular supply of workers brought by Money Ekambi and King Ndumbe from Douala on their launch. ${ }^{67}$ At the same time, the British firm Ambas Bay used its launch to bring workers from the rubber plantations in Calabar paid for by the Cámara. ${ }^{68}$ The main German planter on the island, W.A. Moritz, was provided with workers from the plantation of a family friend located near Mount Cameroon. ${ }^{69}$ According to the testimony of one "Freeboy Calabar", the important Fernandino planter J.W. Dougan was supplied with large numbers of workers from the Eyamba ward in Calabar. ${ }^{70}$

The professionalized recruiters were predominantly Efik and they brought over Ibibio and Igbo canvassed by the riverside markets of their hinterland and, certainly at first, the surplus of slave descendants from their own towns. The word Efik literally means "oppressor" in the Ibibio languages, of which the Efik language is a dialectical group. It is no surprise that most of the dedicated recruiters lived in Calabar and Umuahia near Bende, ${ }^{71}$ for between those two towns was a well-worn trading route along Enyong Creek, the main tributary of the Cross River that connects Itu, Bende, and Afikbo, all of which had had large slave markets. In the late eighteenth century the route became one of the main arteries of the Atlantic slave trade that poured out of Old Calabar, until the British government restrained its own slave traders. ${ }^{72}$ By the mid-nineteenth

to disentangle itself from complete dependency on Nigeria and continued to pursue indentured labour treaties throughout the world, asking for at least 10,000 workers on 5-year contracts. See AMAE, R 887 E-52, R 32 I5 E-56; AGA, C-81/08095, C-8I/08147, C-8I/12373; and Max Liniger-Goumaz, "La cuestión bracera. Ciento cincuenta de búsqueda de mano de obra en Guinea Ecuatorial”, Estudios de Asia y Africa, 22 (1987), pp. 497-534.

67. The Resident of Cameroons Province to GG, 3 I October I93 I, AGA, C-8I/08 I 46, E-I.

68. Curaduria, 3 November I932, C-8I/08I25, E-4; Cámara to GG, I6 December 1930, 8I/08095, E-I 8.

69. German planters in Cameroon complained of the "efforts of Fernando Poo's planters, to whisk away our workers"; see Westafrican Plantation Company Victoria to Kemner, 20 May I926, Bundesarchiv, Berlin-Lichterfelde [BArch], R I001/3504.

70. Curaduria, 6 June 1932, C-8 I/08 I 26, E-2 I. Members of the Eyamba family, from the most commercially and politically powerful lineage of Calabar, had settled on Fernando Pó in the late nineteenth century; Ivor Miller, Voice of the Leopard: African Secret Societies and Cuba (Jackson, MS, 2009), p. I28. For the rise of the free marketeers of the Eyamba ward at the expense of the "landed interests" of Duke Town, see Patrick Manning, "Slave Trade, 'Legitimate' Trade, and Imperialism Revisited: The Control of Wealth in the Bights of Benin and Biafra", in Paul E. Lovejoy (ed.), Africans in Bondage: Studies in Slavery and the Slave Trade (Madison, WI, I986), pp. 203-233.

7I. List of forty known recruiters in Michie, "Labour Conditions in Spanish Guinea" (28 February 194I); list of another forty recruiters and hundreds of canoe paddlers in Policia Colonial, i 2 December 1942, AGA C-8I/I 5865 , E-I 2.

72. For the role of the Aro traders and the failed abolition along the same route, see G. Ugo Nwokeji, The Slave Trade and Culture in the Bight of Biafra: An African Society in the Atlantic 
century the seven Efik towns had a slave population of 95 per cent, and it was they who produced food surpluses and operated the canoes transporting palm oil. ${ }^{73}$

Duke Town had grown to be the wealthiest Efik town due its advantageous location on the Cross River. Duke Town was called Old Calabar by British merchants and was the site of the first British missionary establishments and later the capital of the Southern Nigeria Protectorate. In the years following World War I, with the construction of a railway from Enugu to Port Harcourt, extensive road building, the emergence of small-scale Igbo bicycle traders, and the market occupation by a handful of European import-export firms, the hitherto obligatory economic passage point of Calabar was eclipsed. Merchants from the coastal trading groups found themselves virtually transformed from "wealthy entrepreneurs to petty traders". ${ }^{74}$

While a large proportion of Efiks were employed in colonial administration or in British mercantile firms across Nigeria, for others with a status less guaranteed by the quid pro quo of colonial rule, the only choice was to continue to deploy their canoes and reposition themselves as middlemen in new markets. ${ }^{75}$ The Efik gentry who had maintained their wealth invested in urban property, acquired lorries, and "owned most of the canoes that plied the river and sold most of the spirits that were found in the market". ${ }^{76}$ The new sources of income from recruitment were accompanied by downward social mobility of low-caste Efiks, who aspired in the opposite direction from agricultural labour, which was

World (New York, 2010); Adiele E. Afigbo, The Abolition of the Slave Trade in Southeastern Nigeria, I885-1950 (Rochester, NY, 2006), pp. 33, I 56. British merchants continued to dock in Old Calabar for palm oil; see Martin Lynn, Commerce and Economic Change in West Africa: The Palm Oil Trade in the Nineteenth Century (Cambridge, 2002), pp. 37, 61.

73. Slaves continued to be sourced from districts such as Bende and Uyo; Rosalind Hackett, Religion in Calabar: The Religious Life and History of a Nigerian Town (Berlin, 1989), pp. 20-30; Geoffrey Johnston, $O f$ God and Maxim Guns: Presbyterianism in Nigeria, I846-I966 (Waterloo, ONT, I988), p. 275. For an overview of the extensive and classic literature on the history of the Efiks, see Paul E. Lovejoy, Transformations in Slavery: A History of Slavery in Africa (Cambridge, 2000), pp. 102-104, I87-1 89.

74. Anthony Nwabughuogu, "From Wealthy Entrepreneurs to Petty Traders: The Decline of African Middlemen in Eastern Nigeria, 1900-1950", Journal of African History, 23 (1982), pp. 365-379. This powerful middleman status was lost by many coastal groups across much of West and Central Africa.

75. Adiele E. Afigbo, The Warrant Chiefs: Indirect Rule in Southeastern Nigeria, I89I-I929 (New York, 1972), pp. 27-3r. D. Simmons, "An Ethnographic Sketch of the Efik People", in Daryll Forde (ed.), Efik Traders of Old Calabar (London, 1956), pp. I-26.

76. Nwabughuogu, "From Wealthy Entrepreneurs to Petty Traders", p. 369. For the famous "canoe-houses" west of Calabar, see Patrick Manning, "Merchants, Porters, and Canoemen in the Bight of Benin", in Catherine Coquery-Vidrovitch and Paul E. Lovejoy (eds), The Workers of African Trade (Thousand Oaks, CA [etc.], 1985), pp. 51-74. 
heavily stigmatized as work for slaves. While he was in Santa Isabel, an Efik recruiter named Ben Bassey submitted a letter of complaint to the British Vice-Consul:

On Tuesday I happened to meet my younger brother unexpectedly in the street. I requested how they manage to come here. I was to understand that they were brought here by one trader [known as the "Dahomey woman"] who deceived them that they will be employed as shop-boys on Fonda-sellers [African grocery store]. On this account the children followed her. But now she wishes to sign them in the farm. They are boys and do no farm work because they were in school all the time. ${ }^{77}$

The most competitive side of Efik social organization emerged from the internal dynamics of the Ekpe society. This politico-religious organization spanned all seven towns, all men could and were pressured to be members, and wealth accumulated from trading was the primary criterion for determining status. A large sum of money was required to rise higher than the "young adult" rank of the first two gradients, a rank which also tended to mark the upper limit of membership for individuals from former slave families. ${ }^{78}$ Above that was the "middle-management" level of monetized membership that was central in propelling recruitment, as ambitious Ekpe members could draw upon the patronage of and hire the canoes owned by the wealthy elite. Even the Ekpe society's musicians propagated or at least ideologically reflected recruitment, as the lyrics of an Ekpe chant attest: "You say you are unemployed, if you are jobless let's go to Panya" ${ }^{79}$

The hierarchical networks of labour mobilization that were organized from Calabar came into competition with the much more decentralized recruitment activities of Igbo former labourers and petty traders. The emerging economic prominence of Igbo migrants in Calabar was met with hostility, even to the point of a spate of public attacks on the "foreigners" ${ }^{8 \circ}$ In light of that competition, but only after the eruption of a media scandal

77. Ben Bassey to British Vice-Consul, 2 December 1935, TNA, PRO CO 554/105/3; British Vice-Consul to the Resident of Calabar Province, is January 1936, TNA, PRO, CO $554 / 105 / 3$.

78. Daniel A. Offiong, "The Functions of the Ekpo Society of the Ibibio of Nigeria", African Studies Review, 27 (1984), pp. 77-92, 80. For the different composition of the "leopard" society in Annang country around Ikot Ekpene, which was also called "Ekpe", see Pratten, ManLeopard Murders.

79. Panya was the Pidgin rendering of España or Spanish Guinea, cited in Miller, Voice of the Leopard, p. I28. The song was recorded in Calabar in 1982, by which time the Ekpe society had been largely reduced to recreational and entertainment activities.

80. Pratten, Man-Leopard Murders, p. 194. For the settings of urban economic politics see Ute Röschenthaler, "A 'New York City of Ibibioland'? Local Historiography and Power Conflict in Calabar", in Axel Harneit-Sievers (ed.), A Place in the World: New Local Historiographies from Africa and South Asia (Leiden, 2002), pp. 87-1 10. 
that sought to break the traffic, L.O. Esien Offiong wrote to the Governor of Fernando Pó, proposing that as a

[...] retired member of the Nigerian civil service [...] belong[ing] to the Eyamba House, of the ruling houses in Calabar [he would be] qualified as an experienced and responsible man to run a Labour Recruiting Organisation in Nigeria [which would] remove the abuses, unpleasantness and inconvenience caused by the unlawful system of canoe recruiting and solve finally the labour problem in Fernando Po. ${ }^{8 \mathrm{I}}$

\section{Shanghaiing, brandy, and World War II}

Esien Offiong's proposal was rejected by the Spanish Governor, while cases of "shanghaiing" - a quintessentially British imperial term for being kidnapped to work offshore - shocked the Nigerian media. In Britain, the scandal echoed its way into all major newspapers and even into the House of Commons, and numerous letters of concern were dropped through the letter box of the Colonial Secretary in London by the Anti-Slavery Society. The Nigerian Eastern Mail sparked the controversy in an expose of

$[\ldots]$ the smugglers posing daily at Oron as canoe ferry men [in which] travellers run the risk of unknowingly falling into the hands of the "slave dealers". [...] It is to be deplored that this wicked practice should have been resuscitated by those who thought they could eke out an existence at the expense of the freedom of others. ${ }^{82}$

The recruits were variously described by Nigerian journalists as "unemployed and down and outs", "innocent and unsophisticated Africans" "belonging to the lower walks of life", who were "inveigled", "tricked and bamboozled", "lured - in most cases actually kidnapped by agents who thought of nothing else but the prospect of earning the promised commission on the transaction". 83

It is quite certain that at least io to is per cent of Nigerian braceros on the island had "been taken there without their being willing to go there". That figure was estimated by Timothy Farley Smith, a colonial administrator from Nigeria sent to investigate labour conditions on the island after the media scandal. He arrived at his estimate after "listening to complaints and making inquiries on the Island" and he even excluded

8г. L.O. Esien Offiong to GG, I4 June 1939, AGA C-8 I/08 I3 I.

82. "The Nigerian Eastern Mail Alleges Slavery in Oron", The West African Pilot, 2 I January 1939; newspaper clippings in TNA, PRO, CO 554/1 I4/IO.

83. Shepherd, "Nigerian Labourers in Fernando Po"; "The Fernando Po Slave Traffic", The Nigerian Eastern Mail, 25 February 1939; "Matters of Moment, by Observer", The Nigerian Daily Times, is July 1939. For further bad press, with commentators and student groups even calling for an invasion of the island, see Bolaji Akinyemi, "Nigeria and Fernando Poo, 1958-1966: The Politics of Irridentism", African Affairs, 69 (1970), pp. 236-249. 
from it those "for whom it is natural that having gone willingly and finding they do not like the conditions make as good a story as possible in their efforts to return to Nigeria before completing their contracts". From Farley Smith's impression, only

[...] in isolated cases have recruiters been able to lure fully grown men into going to Fernando Po without their knowing that they were going there, but I am certain that the recruiters have induced a considerable number of youths to leave their homes on promises of work in Nigeria or the Cameroons under British Mandate and have taken them to the Island. The usual procedure is to bring the recruits at night down to some small village on the coast or creeks of Calabar province and tell them that in order to get to their destination they have to cross a wide river. [...] The recruits then embark in the canoes and next morning they are well out at sea and it is too late for them to be able to take any action to get away from the recruiter. ${ }^{84}$

Between the canoe owners and the planters on the island there was another set of dedicated intermediaries taking their slice by acting as translators and managers of the recruits. In the words of the most infamous reclutadora, the "Dahomey woman [who the Consul was told] by various Calabar natives here, [was] a notorious recruiter", would act "as a counsellor and friend to the boys in their journey to Fernando Poo". ${ }^{85}$ Louisa Sousa, or the "Dahomey woman [was] regularly going to Nigeria by canoe" and she continuously reappears in the archive as one of a large handful of shanghaiing culprits. One of her victims was Friday Akpan, whose complaint was pithily transcribed by the British Consul:

I was brought here six months ago by a canoeman named Godwin of Abak, Uyo Division. I asked to him to take me to Calabar to join my brother Christian Nkere, but he took me here and handed me to Serra [a large Portuguese planter in San Carlos whose labour manager was Louisa Sousa]. I have not been paid for three months. I went to a farm and reported my trouble to my relative. I was caught there and sent to prison. I am still in the prison. My employer said that she paid a fat sum to Godwin and that I am her slave. ${ }^{86}$

In Calabar there were "huge public notices warning Natives against going to Fernando Po" that highlighted the risk of canoes being capsized by tornadoes near the island's shark-infested waters. ${ }^{87}$ The newspapers pressed

84. Farley Smith, 2 I September 1939.

85. British Vice-Consul to the Resident of Calabar Province, is January 1936, TNA, PRO, CO $554 / 105 / 3$.

86. Consul General to Governor of Nigeria, 3 March I 943; "General Report No. 3 on Situation in Fernando Po", TNA, PRO, FO 371/34772; British Consul to Consul General, 30 November 1944; "Native Labour, Monthly Report", TNA, PRO, FO 371/49598.

87. British Vice-Consul to the Resident of Calabar Province, I4 January 1939, TNA, PRO, CO $554 /$ I I $4 /$ IO. 
both governments "to accelerate action against this abominable canoe traffic, in order that some plan be formulated whereby Nigerians could travel like human beings, and not after the manner of sacks of palm kernels" ${ }^{88}$ In the summer of 1939, during his inspection tour of Fernando Pó, Farley Smith had already initiated the meticulous drafting of a labour treaty in accordance with the recently ratified ILO conventions. But with the outbreak of World War II the incipient canoe traffic, which the new treaty had aimed to replace, turned into a bazaar-like bonanza.

The smuggling of labourers had become embedded in the increasingly profitable contraband trade, where "anyone, with enough money to hire a canoe and paddlers [went] into this business. [...] There is no one central organisation, the smuggling is almost universal". Those allegedly involved in smuggling were "the rank and file of police, customs and immigration officers, [who] are exposed to enormous temptation", as well as "Senior Police, Europeans and prominent Africans". 89 The smuggling was an open secret hovering across colonial Calabar. A contemporary anthropologist, undertaking fieldwork in Eket, noted that her informants were "extremely reluctant to reveal their true incomes, $[\ldots]$ to reveal certain illegal sources of revenue, notably Brandy smuggling from Fernando Po" $9^{\circ}$ The "Santa Isabel-Oron-Calabar traffic in contraband goods [went on to become] the heaviest along the coast of Nigeria and indeed of West Africa". ${ }^{\mathrm{I}}$ During World War II, the island was wholly dependent on Nigeria for foodstuffs and other vital commodities such as pesticides, petrol, and motorcycles, while barrels of palm oil and rubber were even re-exported to Spain. In exchange, all sorts of Spanish goods were brought back on the canoes, but the bulk of the return cargo was brandy. Thousands of crates found their way into all corners of Nigeria..$^{22}$

88. Shepherd, "Nigerian Labourers in Fernando Po".

89. Commissioner of Police to Governor of Nigeria, "Illicit Traffic between Nigeria and Fernando Po", 2 June 1944, TNA, PRO, FO 371/3966r.

90. Anne Martin, The Oil Palm Economy of the Ibibio Farmer (Ibadan, 1956), p. 17. Brandy, along with "the fear of high tax assessments" from clip-board-holding anthropologists, made the on income the least satisfactory part of [Martin's] budget enquiry". There is even a popular adolescent's book about the seedy Calabar smuggling dens: Rosemary Uwemedimo, Akpan and the Smugglers (Lagos, 1965). For food smuggling from Aba to Fernando Pó and elsewhere, see Gloria Chuku, Igbo Women and Economic Transformation in Southeastern Nigeria, 1900-1960 (New York, 2005), pp. I IO-I I 2.

91. "Smuggling - Nigeria's curse", Drum, January i 96r. By then, the commercial Efik class had lost its last vestige of autonomous economic power. "The Cross River and its main tributary the Enyong Creek [had] become notorious highways for smuggling of goods, including alcohol, tobacco, drugs, and cloth from Fernando Po. Calabar remains the base of this illegal trade which [was] dominated by Bende Ibos"; Reuben K. Udo, Geographical Regions of Nigeria (Ibadan, I970), p. 9I.

92. Imported gin from northern Europe declined tenfold between I929 and 1939; Dmitri van der Bersselaar, The King of Drinks: Schnapps Gin From Modernity to Tradition (Leiden, 2007), 
The chief of the Calabar police, investigating the labour trafficking, had good reason to claim that there was "great difficulty in enlisting the help and cooperation" of the public. ${ }^{93}$ Calabar was the site of the first Nigerian naval base, established there expressly to stop illegal recruitment and liquor smuggling, as customs revenues from alcohol constituted the golden lining of the colonial treasury. However, no patrol launches were available until the final years of World War II, and in any case they were ineffective in stamping out the canoe convoys, which would scatter in all directions if pursued. The canoe operators came to know the timetable of the naval patrols - so they set off only when the launch was being refuelled! Furthermore, the innumerable twisty creeks of the Cross River Delta were impossible to police, and even if they did catch the smugglers "the four naval officers [found it] difficult to take up to 40 Africans in belligerent mood aboard the vessel". ${ }^{94}$ The British Empire controlled the eastern Atlantic, and even throughout World War II the vast shipping routes were regulated by sailing permissions or "navicerts", but imperial ticketing systems were powerless in the Bight of Biafra.

\section{The labour treaty agency, blood papers, and reenganchos}

Meanwhile, Farley Smith's labour treaty was being drafted and re-drafted, before finally being signed by the British and Spanish colonial authorities in December 1942.95 The attempt to redraw, standardize, and supervise the recruitment trajectory involved the construction of an obligatory passage point for all labour intermediaries. All contract formalities and medical tests would be processed by the British authorities before boarding. The John Holt Company in Calabar was put in charge of hiring licensed recruiters, under the "newspeak" organizational name of the "Anglo-Spanish Agency for Contracting and Protecting Calabar Labourers". ${ }^{6}$ The agency set out to become a monopoly, but it had scant

p. I87. And for how much was at stake in terms of colonial revenues, see especially Chima J. Korieh, "Alcohol and Empire: 'Illicit' Gin Prohibition and Control in Colonial Eastern Nigeria", African Economic History, 3 I (2003), pp. I I I-I 34, I I 9.

93. "The Nigerian Eastern Mail Alleges Slavery in Oron", The West African Pilot, 2 I January 1939. 94. Commissioner of Police to Governor of Nigeria, 2 June 1944. This is similarly recounted in the memoir of a marine officer, P.J. Odu, The Future That Vanished: A Biafra Story (n.p., 2009), p. 70: "I never once caught a smuggler".

95. Colony and Protectorate of Nigeria and Spanish Territories of the Gulf of Guinea, "Treaty Regarding the Recruitment in Nigeria of Native Labourers for Working in the Spanish Territories of the Gulf of Guinea", 9 December 1942; available online at: http://treaties.un.org/doc/ Publication/UNTS/LON/Volume\% 20205/v205.pdf (last accessed is April 2012). For the long series of drafts, disharmonies, and scribbles, see AGA, C-8I/08I 3 I. The Spanish fascist government suspected that the treaty was an imposition by "Geneva" conspiring against them. 96. Nkparom Ejituwu, "Anglo-Spanish Employment Agency: Its Role in the Mobilization of Nigerian Labour for the Island of Fernando Po", in A.I. Asiwaju, B.M. Barkindo, and 
success as the recruiters circumvented the new requirements of the treaty, which prohibited individual planters from paying premiums. Even one official licensed recruiter stationed in Opobo, handing out flyers with pictures of model plantations, would bring the recruits to Sambo Ekpo, a canoe operator in Oron, instead of to the agency's transit camp. ${ }^{97}$ For the first few years only around i 50 monthly work contracts were overseen by the agency, and it was only in the late i950s that braceros brought in under the new arrangements began to outnumber illegally recruited workers. ${ }^{98}$

The treaty's first article, which was also its stated aim, prohibited those arriving outside the protocols of the treaty from being placed under contract. However, those already working on the island before the treaty was signed could renew their contracts, although the majority did not. ${ }^{99}$ Those finishing their contracts turned to trading or left the island and sold their Spanish medical examination results or "blood papers" to the counterfeit dealers in Calabar. With those "blood papers", the new recruits arriving clandestinely on canoes would start working under false names as re-contracted pre-treaty labourers. While many of those arriving saved themselves the trouble and claimed they had set off from the French Cameroons, for those reenganchos (officially under a second contract) the wages were 60 pesetas a month, twice that of braceros under a first, or a treaty contract. ${ }^{100}$ The increase in pay had been put in place to prolong the contracts of workers who were already familiar with the labour-intensive procedures of cacao production, which entailed constant

R.E. Mabale (eds), The Nigeria-Equatorial Guinea Transborder Cooperation (Lagos, 1995), pp. 42-57. It was later renamed the "Anglo-Spanish Employment Agency", and the "branding" talk very consciously avoided the term "recruitment".

97. British Consul to Don Juan, ir June 1946, AGA, C-81/8130 E-1; Consul General to Governor of Nigeria, 3 March 1943; list of licensed recruiters in Nigeria, "Annual Report of the Department of Labour, Nigeria, for the year I944", TNA, PRO, CO 657/53.

98. British Consul to Consulate General, 6 July i943, TNA, PRO, FO 371/34772; Esteban Hanza to GG, June 1962, AGA, C-8I/082 I4 E-I.

99. Wolff, "Ein Beitrag zur Wirtschaft von Fernando Poo", p. 98. Wolff was stuck in Fernando Pó at the outbreak of World War II, and he wrote that "usually the Gastarbeiter returned home with three to five pounds in savings". Spanish officials used the resulting statistically high recontracting rate as "proof" of the good working conditions.

I00. Some planters even offered a lump-sum bonus, a real regalo, for recontracting for another two years. In 1944, it was I,000 pesetas or $£_{20}$, higher that the first two years of wages; British Labour Officer at Fernando Po to Consul General, 26 May i944, TNA, PRO, FO 371/3966I. Food rations, housing, and health costs were covered by the plantation owners. Living expenses were very low compared with the cost of living in Nigerian cities and towns. There were also many opportunities by which workers could increase their income. It was very common for Nigerian braceros to sell a combination of their imported food rations as well as any bush-meat, river crabs, and fruits gathered from the shadow trees planted alongside the cacao. That was the main reason why an employer near the road or town was much to be preferred. 
clearing of vegetation, maintenance of plant nurseries, transplanting seedlings, spraying trees with sulphate, estimating ripeness, harvesting cacao pods with long-handled sickles, fermenting and drying the fruit, and classifying and bagging the beans.

Forgery of second contracts was what kept illegal recruitment going, as without the reengancho bonuses wages on the island were, by the end of World War II, lower than in Nigeria, as "due to army separation allowances and the present food produce prices, there [was] plenty of money in circulation and it [was] possible for a labourer to earn a favourable living locally". ${ }^{\text {Io }}$ Planters regularly used the contracts of braceros who had died to sign up clandestine recruits under false names. ${ }^{102}$ On the surface, the Curaduria had to have its paperwork appropriately ordered to accommodate the Treaty's stipulations and the British Consul's inspections. By I945 the Calabar police had arrested hundreds of smugglers, and at the

[...] Nigerian end, the labour smuggling [that remained was] in the hands of a chosen few, [among whom was] the Dahomey woman, who [was still] notorious as a smuggler of labour and contraband goods, [...] as is the case on the Island where the traffic [was] controlled entirely by about 3 persons with the full knowledge and connivance of Officials in High Authority.

It was both the chief of the Spanish police and his brother the labour officer whom a handful of the most important recruiters had in their pockets. ${ }^{103}$ As the supply of "blood papers" was dwindling, Sebastian Llompart Aulet (the labour officer until the I960s), would, for a 50-peseta bribe, stamp forged contracts that made it appear that the new recruits were re-contracting. "As with the smuggling of contraband goods, the sum of 1000 pesetas is collected by the chief of police and 500 pesetas by the owner of the beach where the canoes arrive", who would also take the recruits "over to San Carlos for distribution". ${ }^{104}$

Polite requests - almost amounting to injunctions - to shut down illegal recruitment were made by the British Consul in almost every communication with Spanish officials. The Cámara would of course point to the inevitability and indispensability of the clandestine recruiters, as "the supply of labour is

Iог. F. Shepherd to British Consul, 6 December 1944, AGA, C-8г/08г30, E-r. The official wage on Fernando Pó until I 946 was 30 pesetas, or I4 shillings, 6 shillings short of $£_{\mathrm{I}}$.

102. Fernando García Gimeno, Fernando el africano (Madrid, 2004), pp. 45-50. This is the memoir of a humble and unpretentious Spanish settler who spoke "Pichinglish" and who, between 1950 and 1964, managed 600 Nigerian braceros at any one time for several Portuguese and Bubi planters.

103. British Consul to Consul General, 30 December 1944, TNA, PRO, FO 371/49598.

104. British Consul to Consul General, 23 July i944, TNA, PRO, FO 371/3966r. The supply chain was geared towards the remote San Carlos and to the large Fernandino and Portuguese planters, who had been cut out by the official recruitment channels which prioritized Spanish planters. 
far less than the demand [ $\ldots$ and besides] Nigeria is overpopulated". To make its point quite blatantly, in I945 the Cámara petitioned the British Consul to increase the Treaty quota from 400 labourers a month to I,200 for the island in addition to a further 3,400 monthly contracts needed for the projected growth of logging works and coffee plantations in Rio Muni, and signed off with an impertinent bottom line of 55,000 braceros per year. ${ }^{105}$

\section{CONCLUSION - AGENCY, MEDIATORS, AND INTERMEDIARIES}

The basic lesson in economics given to the Consul by the Cámara should not be mistaken for a conclusive hypothesis for the underlying explanation as to why clandestine recruiters enjoyed such success in the Bight of Biafra. The single cause of exploitation and efficiency is formulated by experts through a variety of legitimated formulae, and only then can labour surplus/scarcity be seen as a wave "simply transported without deformation through a chain of intermediaries".

To study empirically the metrics of capitalism-imperialism, it can be helpful to abandon the contrivances of Marxist schemata and the idea of roaming but placeless homines economici. Replacing those with the actual toil of constant action and constant connection, without which the contorted landscapes of history would not have come into existence, allows for a precise account of the delicate and brutally imposed contours of world-systemic economic trajectories. Only once a great many material instruments and ideological scripts have been mobilized can a configured network give the impression of being either something "local" or a durable global structure commanding predictable intermediaries to do its bidding. ${ }^{\mathrm{o} 6}$ ANT provides the methodological tools to unfold structures, flatten the global, and to disperse or "dislocalize" action. By following the procedures of ANT we are led to the conceptual dissolution of binary pairs and of the manifold sociological compromises - their "dialectical mutual constitution", or their "interdependence" - that keeps them intact.

The single scope and object of analysis in Latourian ANT is the actormediator, or "actant", which transports and translates a network that is

ı05. British Consul to Cámara, 20 October 1948, AGA, C-8 I/08 r 24, E-I; Consul General to Governor of Nigeria, I 2 February 1945, "Native Labour, Monthly Report, No. I2", TNA, PRO, FO 371/49598. At this time about one-third of the still comparatively smaller workforce in Rio Muni was from Nigeria.

I06. Latour, Reassembling the Social, pp. 60, 204. For this line of post-structuralist thinking, where "movements and displacements come first, places and shapes second", and that should not easily be dismissed as a mere symptom of the neoliberal World Wide Web "age" but treated as a theory of history that diverges scientifically and politically from the critical style of analysing "global capitalism", see also J.K. Gibson-Graham, The End of Capitalism (As We Knew It): A Feminist Critique of Political Economy (Minneapolis, MI, 2006). 
always on site, being performed, stabilized, undermined, or reconstructed. As noted in Graham Harman's wonderful book on Latour, for Latour there exist only more or less powerful actants. In the autonomy- and resistance-defined notion of agency, agency is a human privilege that lies below a constraining structure. However, if power, structure, and agency are released from humanisms and dualisms and are said to be distributed throughout a socio-technical network, it does not mean that they are diffuse or horizontal.

The braceros were literally surrounded, and even though they had to enter into and go through what could be described as the ordeal of colonial modernity, they never lost the ability to move and to become mediators themselves. In Rio Muni, the theft of regalos, flight, and border crossing eventually led to the abolition of the whole wage-regalo recruiting arrangement. Nigerian braceros increased their share of wealth produced in the Spanish colony by unflinchingly supplying markets with second-hand documents and contraband commodities. It was their initiative to bring to official attention the abuses of the recruiters by submitting complaints to the Consul and by exposing stories to journalists, and therefore of creating the traces that populate the archives.

A good critique of ANT is that it tends to protagonize exceptional actors and "winners", such as colonialists or recruiters, as their victory depends on being part of the dominant associations that leave behind the most traces and sources. ${ }^{107}$ The colonial economic project could spread by aggressive force and maps of battlefields, through plenary imperial mandates and administrative paperwork or in racist and intimidating legal-symbolic status regimes. Within geo-imperial coordinates the activities of Fernando Pó's recruiters working with their allies, compatibilities and preconditions could unfold, specifically through, in Rio Muni, Fang gender and status hierarchies, bridewealth, and peseta coinage; and in Nigeria through the logistical infrastructure of merchants in Calabar, the legacies of the Atlantic slave trade, and the relentless cutting of prices in the palm-product market.

The position of the clandestine recruiters as indispensable and quite durable relay points for the mobilization of labour across the Bight of Biafra was meticulously created by a long list of mediators which cannot be disentangled and formalized into the purified combinatory matrix characteristic of structuralist social theory. Rather, in a diagrammatic

107. For a critically sympathetic view see Graham Harman, Prince of Networks: Bruno Latour and Metaphysics (Melbourne, VIC, 2009). Apart from Latour's work, Harman's book has been the most inspiring for an attempt at ANT-inflected historical social science research, although the British branch of ANT is more closely associated with illuminating the operations of imperial expansion. See, for example, John Law, "On the Methods of Long Distance Control: Vessels, Navigation and the Portuguese Route to India", in idem (ed.), Power, Action and Belief: A New Sociology of Knowledge? (London, 1986), pp. 234-263. 
fashion, to deploy themselves, the labour intermediaries aligned with the organizational standards of and translations between kinship, ethnicity, money, gender, psychology, law, bureaucracy, religion, war, commodities, and so on.

The composition of the recruitment trajectories partially followed up on in this article included: subsidized Spanish chocolate; the currencies deemed acceptable for paying bridewealth; police uniforms; the control of wealth by chiefs; regalos and the colonial state's currency and price regulations; the structure of the contract; the ability to make false promises and convincingly deceive; the fraternal relations between the Spanish police chief and the labour officer; the documentation required for boarding ships and taking up contracts; IOUs; bombs bought with foreign exchange reserves dropped by the Francoists in Madrid; bottles of brandy; home-town associations; the organization of Ekpe membership; forged second contracts; and the one navy vessel that was transporting Nigerian soldiers during World War II instead of patrolling the Cross River Delta.

It was within these serialized mediators, not adjacent to some sort of wider context or below pre-produced structures or somewhere outside the concrete, that the recruiters organized a treacherous path between capital and labour - or, with the details unfolding, between this mediated capital and that mediated labour. 